\title{
DEVELOPMENT OF A LOW THERMAL EXPANSION, CRACK GROWTH RESISTANT SUPERALLOY
}

\author{
John S. Smith and Karl A. Heck \\ Inco Alloys International, Inc. \\ Huntington, WV 25705-1771
}

\begin{abstract}
Low thermal expansion superalloys have been used for a number of years in a variety of applications, including gas turbine engines. The low thermal expansion characteristics of the most widely used class of matertals are derived from the ferromagnetic characteristics of $\mathrm{Ni}, \mathrm{Fe}$, and $\mathrm{Co}$ based austenitic matrices containing little or no $\mathrm{Cr}$. Over time, a progression of alloy developments ensued, aimed at improving the oxidation resistance and stress accelerated grain boundary oxygen (SAGBO) attack. While notch rupture tests have been used to screen for the SAGBO phenomenon, a more sensitive measure of this characteristic is the sustained load crack growth test performed in air.

This paper describes some final iterations in the development of a new class of low expansion superalloys utilizing high Al content and $\gamma, \gamma$, and $\beta$ phases in the microstructure. Such alloys provide good general oxidation resistance, and rupture strength and ductility, and varying degrees of crack growth resistance. A number of designed factorial experiments were carried out to optimize $538^{\circ} \mathrm{C}$ crack growth resistance, yet maintain a balance of other important engineering properties. These experiments included examinations of $\mathrm{Ni}, \mathrm{Fe}, \mathrm{Co}$, $\mathrm{Cr}, \mathrm{Nb}$, and $\mathrm{Ti}$ content combined with heat treatment studies. $\mathrm{Al}$ content remained essentially fixed on the basis of prior development work. Tests performed included thermal expansion, tensile, tensile and Charpy impact stability, stress rupture, creep, $538^{\circ} \mathrm{C}$ static crack growth, and microstructural analysis.
\end{abstract}

These studies showed, that for a given heat treatment cycle, a small amount of $\mathrm{Cr}$ combined with increased Co content in place of $\mathrm{Ni}$ provides a decrease in crack growth rate. Furthermore, the small $\mathrm{Cr}$ addition improves salt spray resistance, yet the addition is small enough as not to significantly affect thermal expansion performance. The crack growth rate was also reduced with increased Co content replacing $\mathrm{Ni}$. The final alloy composition was designated INCONEL $B$ alloy 783 .

Crack growth rates were affected by heat treatment. Microstructural examinations showed heat treatment affected amounts of globular $\beta$ phase present after hot working and annealing, and amounts of the phase re-precipitated within grain boundaries or intragranularly. Slower propagation rates correlated with increased volume percent of $\beta$ phase with lower temperature anneals, or increased amounts of $\beta$ phase precipitated in grain boundaries after high temperature anneals and " $\beta$-aging" at intermediate temperatures. A high temperature anneal was selected for compatibility with high temperature braze cycles without significantly coarsening grain structure. An appropriate $\beta$ age was determined for good rupture and crack growth properties. Heat treatment studies further showed that higher yield strengths are achieved with treatments incorporating slow cooling within the $\gamma^{\prime}$ precipitation range. A final aging treatment compatible with other superalloys, such as alloy 718 was therefore selected for optimum tensile strength.

Alloy 783 has been successfully produced as VIM-VAR large diameter forging billet, and hot rolled small rounds and flats. Sustained load crack growth data at $538^{\circ} \mathrm{C}$ obtained from seamless rolled turbine engine rings are presented in this paper. Alloy 783 has been successfully welded and fabricated into gas turbine engine components that are under evaluation by gas turbine manufacturers.

B INCONEL and INCOLOY are trademarks of the INCO family of companies.

\section{Introduction}

For over two decades research has been directed at developing controlled low thermal expansion superalloys. ${ }^{1,2}$ These efforts were initially successful in the commercial development of INCOLOY $\$$ alloys 903, 907, 908, and 909. This class of superalloys have found significant commercial usage in industries as diverse as gas turbine engine static parts and superconducting magnets for fusion reactors. However, it has not been possible to fully exploit the advantages of high strength, low expansion materials in elevated temperature designs due to the poor general surface oxidation resistance and their susceptibility to fast crack growth under sustained loading in air at intermediate temperatures.

Several attempts have been made in recent years to address the environmentally related property weaknesses. One alloy development effort ventured into a new class of $\gamma-\gamma^{\prime}-\beta$ superalloys. ${ }^{3}$ This paper discusses the development of crack growth resistance under sustained load at intermediate temperatures in the $\mathrm{Co}-\mathrm{Ni}-\mathrm{Fe}-\mathrm{Al}-\mathrm{Nb}, \gamma-\gamma^{\prime}-\beta$ alloy system. The studies described here are confined to the effects of varying $\mathrm{Co}, \mathrm{Ni}$, and $\mathrm{Cr}$ contents, and heat treatments on constant load crack growth at $538^{\circ} \mathrm{C}$, with limited discussion of other relevant properties, that led to the development of INCONEL alloy 783. Other mechanical and physical properties are presented elsewhere. ${ }^{4}$

\section{Procedure and Experimental Techniques}

Development Procedure. The alloy development goal was to simultaneously optimize low thermal expansion, tensile strength and ductility at elevated temperatures, creep strength, stress rupture life and notch ductility, general oxidation and corrosion resistance, stability after long time exposure at intermediate service temperatures. Manufacturing and fabricating simplicity, and compatibility of heat treatments and joining parameters with other commonly used gas turbine superalloys were other factors that were considered advantageous and were evaluated throughout the development project. 
In addition to the above superalloy characteristic goals, the primary goal was to achieve intermediate temperature, sustained load, crack growth resistance. Specifically, it was believed that a $\gamma-\gamma^{\prime}-\beta$, controlled expansion superalloy should have $\mathrm{da} / \mathrm{dt}$ at $538^{\circ} \mathrm{C}$ approaching that of thermomechanically processed, conventionally heat treated, INCONEL alloy 718. Past experience had shown that $\mathrm{da} / \mathrm{dt}$ at $538^{\circ} \mathrm{C}$ was a critical alloy property to optimize if any new controlled expansion superalloy was to gain significant commercial usage. For static engine components, and other applications as well, it appeared feasible to achieve a commercial balance of physical, mechanical, thermal, manufacturing/fabricating, and crack growth properties within the $\gamma-\gamma$ ' $\beta$ alloy system.

Development of INCONEL alloy 783 was by necessity a concurrent development project. Compositions within the $\gamma-\gamma^{\prime}-\beta$ superalloy system were systematically explored via a series of interlocking factorial designs, and were screened for certain properties (such as da/dt). At appropriate points in the development process, certain compositional variations were also subjected to varying heat treatments using factorial designs to determine the compositional-heat treatment interactive and synergistic effects on selected properties. Response surface analyses were utilized to examine "the lay of the land", that is, the effect of two or more factors in combination on a given property. The significantly non-linear and interactive effects of $\mathrm{Ni}$ and $\mathrm{Co}$ on stress rupture life have been shown before, and demonstrate the need for this approach to alloy development.

Since optimization factors included manufacturing and fabricating simplicity, full scale commercial-sized melts were produced using $\gamma-\gamma^{\prime}-\beta$ compositions which were known to be non-optimal in properties. These full scale melts were subjected to various manufacturing processes and evaluated for manufacturing feasibility. Some portions of this approach have been described. ${ }^{3}$

This paper contains some examples of studies aimed at determining the effects of $\mathrm{Co} / \mathrm{Ni}$ and $\mathrm{Cr}$ content, and the interaction of heat treatment on constant load crack growth, with discussion of other properties as relevant.

Compositions and Processing. The compositions evaluated in this paper are presented in Table I. Laboratory heats, designaled by an HV prefix, were vacuum induction melted, $100 \mathrm{~mm}$ diameter, $22 \mathrm{~kg}$ ingots. These were homogenized, cut in half, and hot rolled on a 16 inch Birdsboro mill to 0.750 in diameter round bars and to 0.500 inch by 2 inch flats. Mechanical property test specimens were machined from the round bars and compact tension test specimens were machined from the flats. A few flats and round bars were subjected to mechanical property tests and microstructural evaluations to verify that structure and properties were similar within a given ingot.

Full scale melts, designated with a $Y$ prefix, were vacuum induction melted and vacuum arc remelted. The process history for $Y 9342 Y$ is described elsewhere. ${ }^{3}$ Melt number Y9411Y was one of three vacuum arc remelted $457 \mathrm{~mm}$ diameter by $3810 \mathrm{~mm}$ long ingots. This ingot was homogenized and hot forged and rolled to 203,254 and $305 \mathrm{~mm}$ diameter billets. Seamless rolled rings $50.8 \mathrm{~mm}$ thick by $101.6 \mathrm{~mm}$ high by $610 \mathrm{~mm}$ outside diameter were produced from a $203 \mathrm{~mm}$ diameter billet. These rings were subjected to property evaluations. Heat number $Y 9342 Y$ is representative of non-commercially available $C_{r}$-free $\gamma-\gamma^{\prime}-\beta$ superalloys. Heat number Y9411Y represents the commercial, $C_{r-a l l o y e d} \gamma \gamma^{\prime}-\beta$ superalloy, INCONEL alloy 783.

Testing. Basic room and elevated temperature tensile, combination notch-smooth stress rupture, and thermal expansion testing were conducted in accordance with ASTM Standard Test Methods E8, E21, $\mathrm{E} 139$ and E228, respectively.

Static or constant load crack growth testing was conducted using standard compact tension specimens machined in conformance to ASTM E 647-91. Specifically, compact tension specimens were 7.6 $\mathrm{mm}$ thick by $25.4 \mathrm{~mm}$ wide. Overall outer dimensions were $30.5 \mathrm{~mm}$ by $31.8 \mathrm{~mm}$. Specimens were fatigue pre-cracked in accordance with E647 to provide a starting nominal pre-crack plus notch length of 7.6 $\mathrm{mm}$. Specimens satisfied the validity requirements of E 647-91 section 7.2.1. Static load crack growth testing was conducted at $538^{\circ} \mathrm{C}$ under induction heating in air at an initial stress intensity of nominally $27 \mathrm{MPa} \sqrt{\mathrm{m}}$.

Crack length measurements were recorded using traveling optical microscopes, electrical potential, and compliance techniques. The potential and compliance techniques were calibrated using optical microscopy measurements. Crack growth testing was predominantly conducted at Martest, Inc., where both optical and compliance techniques were used. Some testing was conducted at Inco Alloys International, Inc., using both electrical potential and optical techniques. Crack growth results were found to be reproducible between the two laboratories and across the three testing techniques.

Transient behavior at the initiation of the crack propagation test was typically observed which was comparable to that often observed in superalloy crack growth testing. This portion of the crack growth raw data was ignored for this analysis.

Table I Chemical compositions, weight $\%$.

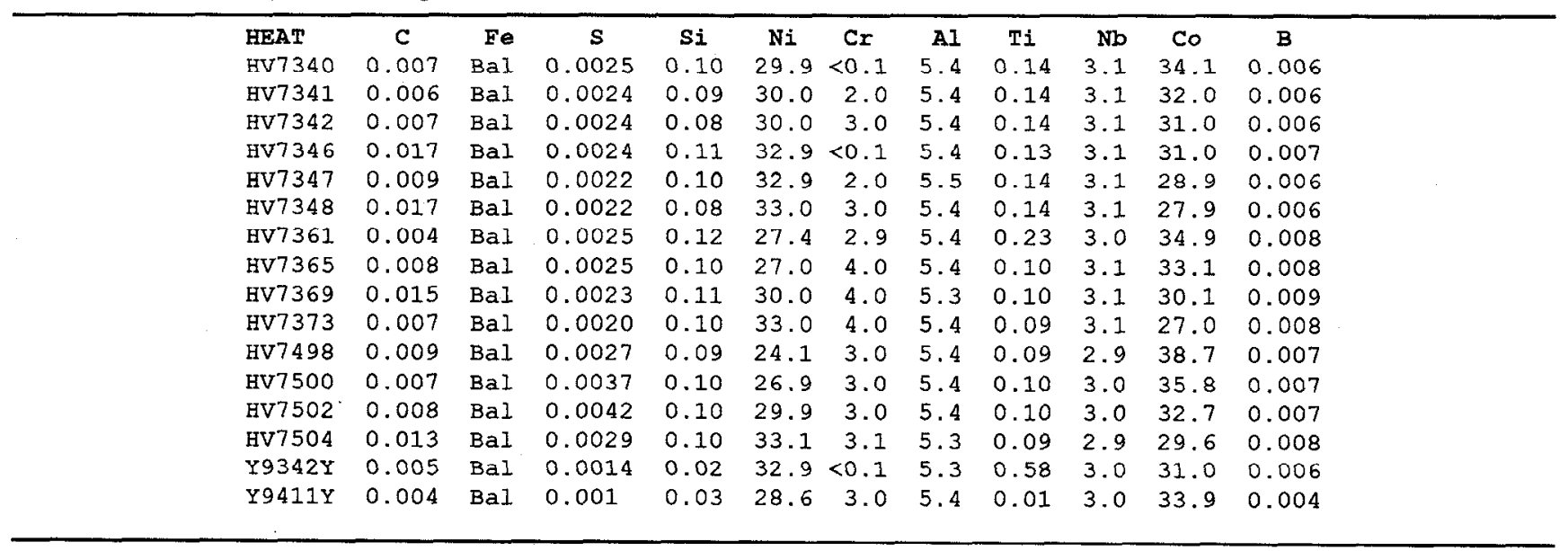




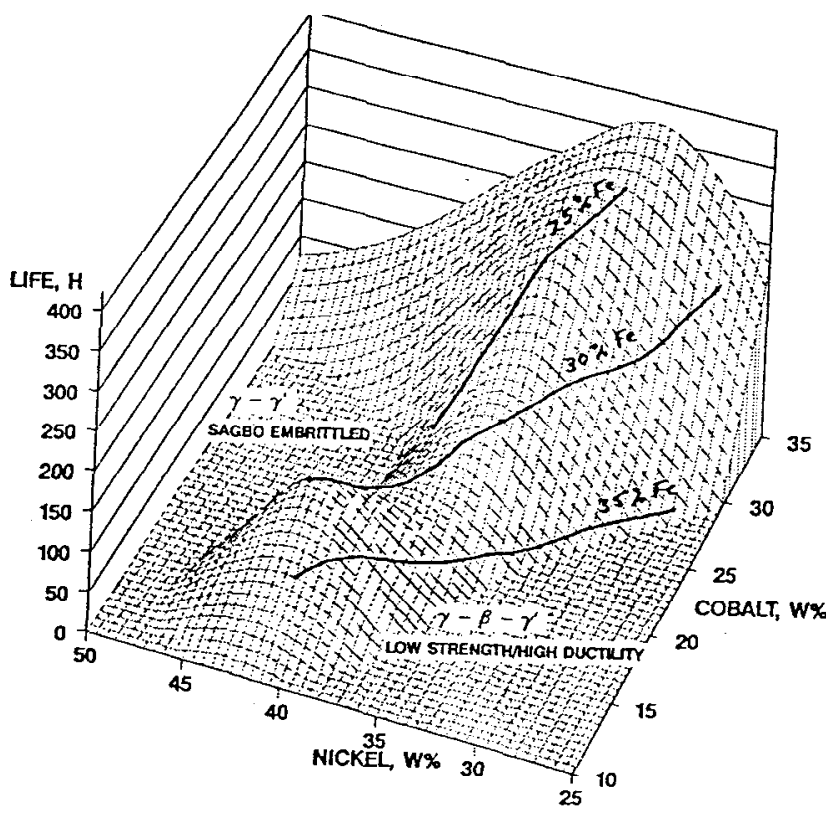

Figure 1 Effect of $\mathrm{Ni}$ and $\mathrm{Co}$ on the stress rupture life at $649^{\circ} \mathrm{C}$ and $510 \mathrm{MPa}$ of $\mathrm{Cr}$-free $\gamma-\gamma^{\prime}-\beta$ alloys. ${ }^{3}$

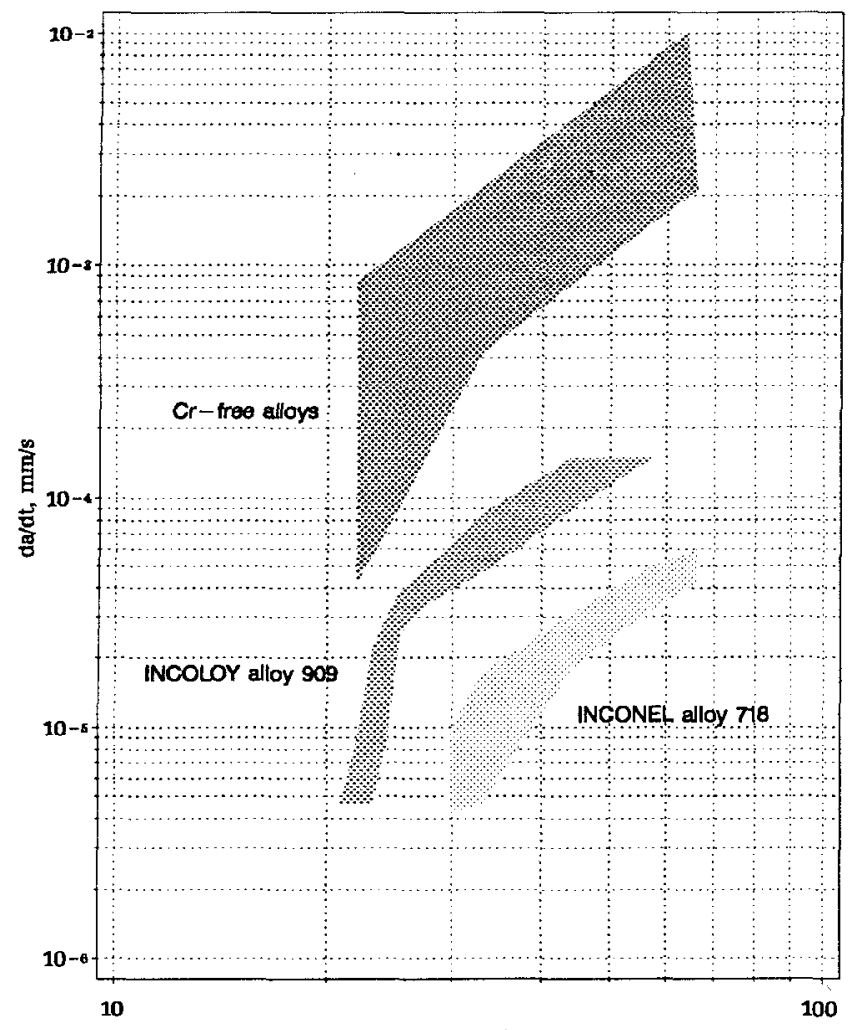

K. MPa $\sqrt{m}$

Figure 2 Comparison of $\mathrm{da} / \mathrm{dt}$ at $538^{\circ} \mathrm{C}$ of $\mathrm{Cr}$-free $\gamma-\gamma^{\prime}-\beta$ alloys, INCOLOY alloy 909, and INCONEL alloy 718.

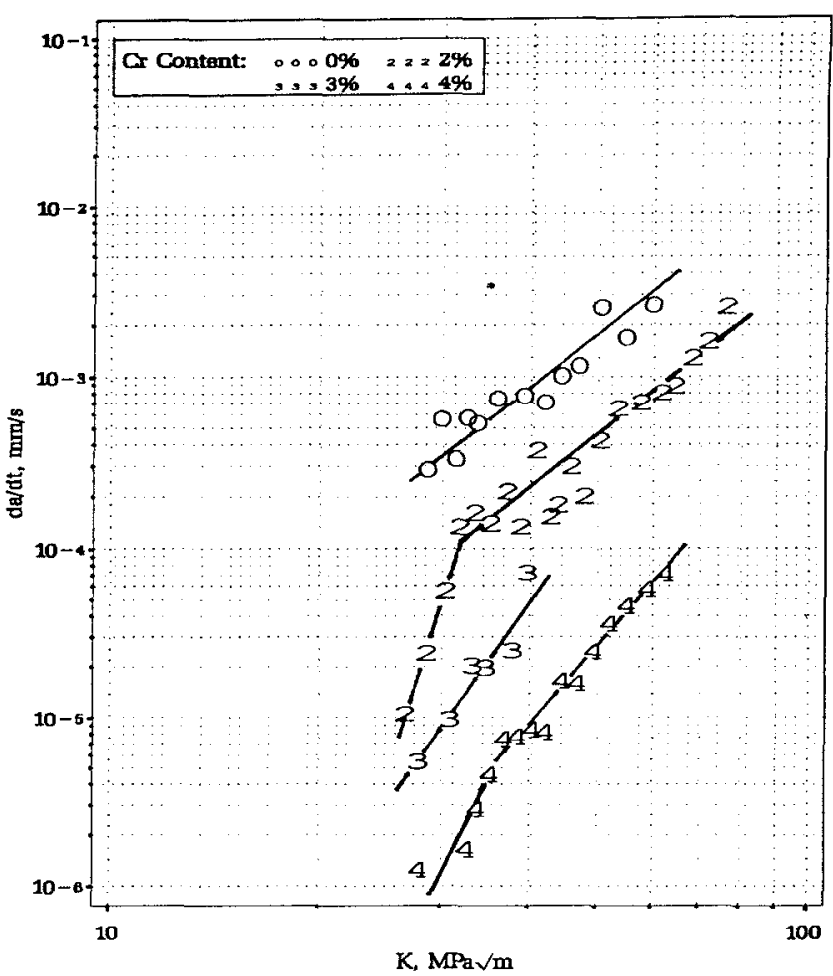

Figure 3 Effect of varying $\mathrm{Cr}$ content on $\mathrm{da} / \mathrm{dt}$ at $538^{\circ} \mathrm{C}$. Nominally $30 \% \mathrm{Ni}, 27.5 \% \mathrm{Fe}, 5.4 \% \mathrm{Al}, 0.1 \% \mathrm{Ti}, 3 \% \mathrm{Nb}$, balance $\mathrm{Co}$. $\mathrm{Cr}$ added at expense of $\mathrm{Co}$.

\section{$\underline{\text { Results }}$}

Crack Growth in $\mathrm{Cr}$-Free $\gamma-\gamma^{\prime}-\beta$ Superalloys. Depending on the selected $\mathrm{Ni}$ and $\mathrm{Co}$ content, $\gamma^{-} \gamma^{\prime}-\beta$ superalloys exhibited good $649^{\circ} \mathrm{C}$ stress rupture life, as shown in Figure 1. Notch rupture lives in excess of the targeted goal were achieved. The full large scale melt $Y 9342 Y$ also showed good $538^{\circ} \mathrm{C}$ notch $\left(K_{t}=2\right)$ rupture properties with lives exceeding $363 \mathrm{~h}$ under $827 \mathrm{MPa}$. These notch rupture properties were significant improvements over existing controlled thermal expansion superalloys and were thought to indicate probable resistance to sustained load crack growth.

However, sustained load crack growth testing at $538^{\circ} \mathrm{C}$ revealed a different situation. As shown in Figure 2, the range of da/dt at $538^{\circ} \mathrm{C}$ for $C r$-free $\gamma \gamma \gamma^{\prime}-\beta$ alloys was actually worse than INCOLOY alloy 909 , despite these same alloys having superior notched stress rupture lives.

The crack growth rate was somewhat sensitive to heat treatment, but no significant improvements were found possible. This data illustrates the potential fallacy of using notched stress rupture data as indicators of sustained load crack growth resistance.

Effect of $\mathrm{Cr}$ on $\mathrm{da} / \mathrm{dt}$ in $\gamma-\gamma^{\prime}-\beta$ Alloys. The effect of varying $\mathrm{Cr}$ content on $\mathrm{da} / \mathrm{dt}$ at $538^{\circ} \mathrm{C}$ is shown in Figure $3 . \mathrm{Cr}$ was added at the expense of $\mathrm{Co}$. $\mathrm{Ni}, \mathrm{Fe}, \mathrm{Al}, \mathrm{Ti}$ and $\mathrm{Nb}$ contents were held constant at nominally $30 \%, 27.5 \%, 5.4 \%, 0.1 \%$ and $3 \%$, respectively. Compact tension specimens were annealed at $1010^{\circ} \mathrm{C}$ for one hour and age hardened at $788^{\circ} \mathrm{C}$ for 16 hours, furnace cooled $55^{\circ} \mathrm{C} / \mathrm{h}$ to $621^{\circ} \mathrm{C}$, held for $8 \mathrm{~h}$, and air cooled. Increasing Cr content from nil to $4 \%$ improved $\mathrm{da} / \mathrm{dt}$ resistance by over 2 orders of magnitude. 


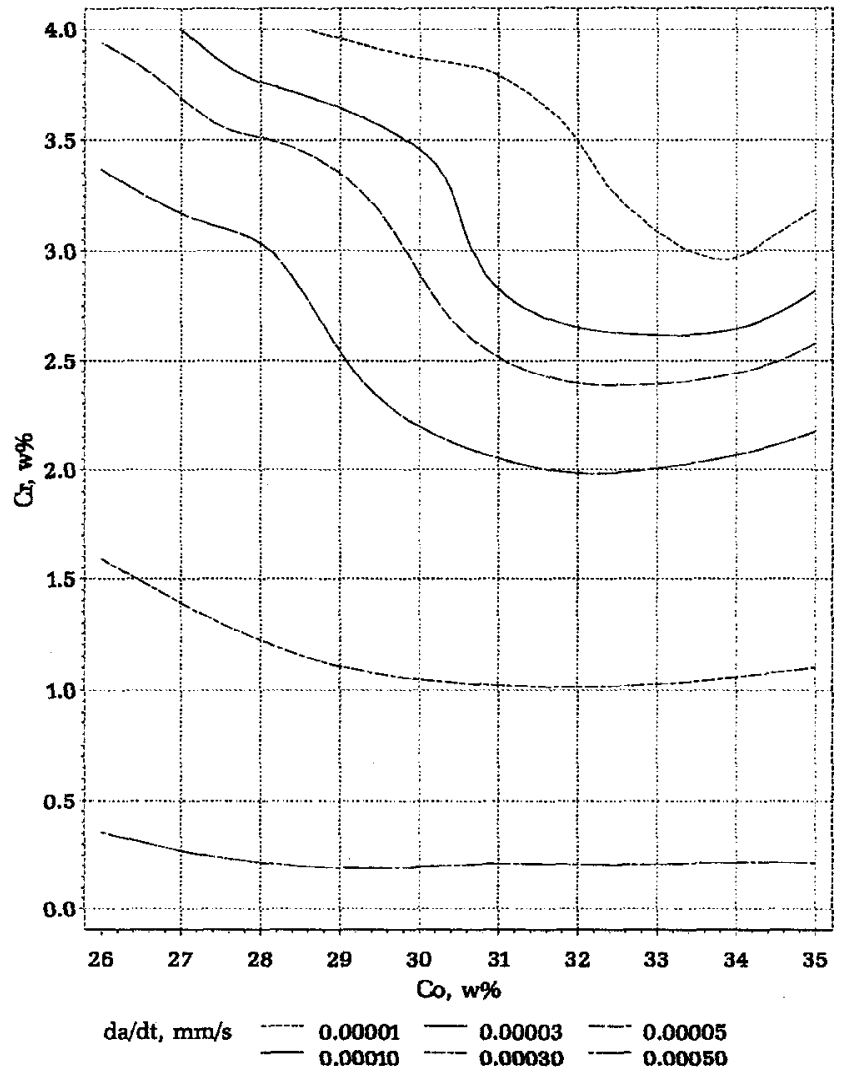

Figure 4 Effect of $\mathrm{Cr}$ and $\mathrm{Co}$ on da/dt at $538^{\circ} \mathrm{C}$ and $33 \mathrm{MPa} V_{\mathrm{m}}$.

Response Surface Analysis: $\mathrm{Cr}$-Co-da/dt. The preceding experiment led to expanded composition factorial studies to define the $\mathrm{Cr}$-Co$\mathrm{da} / \mathrm{dt}$ response surface for alloy specimens annealed at $1010^{\circ} \mathrm{C}$ for one $\mathrm{h}$, air cooled, and age hardened at $788^{\circ} \mathrm{C}$ for $16 \mathrm{~h}$, furnace cooled $55^{\circ} \mathrm{C} / \mathrm{h}$ to $621^{\circ} \mathrm{C}$, held for $8 \mathrm{~h}$ and air cooled. The resulting $\mathrm{da} / \mathrm{dt}$ isocontours versus $\mathrm{Cr}$ and $\mathrm{Co}$, shown in Figure 4, reveal a $\mathrm{Cr}$ Co interaction effect on da/dt in alloys containing greater than $2 \% \mathrm{Cr}$ content. Da/dt decreases with $\mathrm{Cr}_{\mathrm{r}}$ at all $\mathrm{Co}$ levels, but especially at $\mathrm{Co}$ contents greater than roughly $30 \%$. The desired da/dt rates fell within a pocket of greater than $2.5 \% \mathrm{Cr}$ and greater than about $30 \% \mathrm{Co}$ content.

Response Surface Analysis: $\mathrm{Cr}_{\mathrm{r}}-\mathrm{Cor} \varepsilon_{\text {. }}$. The effect of $\mathrm{Cr}_{\mathrm{r}}$ and $\mathrm{Co}$ on the secondary creep rate of specimens tested at $649^{\circ} \mathrm{C}$ under $380 \mathrm{MPa}$ is shown in Figure 5, as creep rate isocontours. Heat treatment was the same as noted above. Creep rate varied as a bowl relationship with $\mathrm{Cr}$ and $\mathrm{Co}$, with minima occurring between 26 and $30 \% \mathrm{Co}$ and 2 to $4 \% \mathrm{Cr}$. While increasing Co content increased the creep rate for any given $\mathrm{Cr}$ content, increasing $\mathrm{Cr}$ content up to $3.5 \%$ decreased the creep rate. It was therefore possible to offset losses in creep strength due to increasing Co content (for added da/dt resistance) by also increasing $\mathrm{Cr}$ content.

Effect of $\mathrm{Co} / \mathrm{Ni}$ content and heat treatment on $\mathrm{da} / \mathrm{dt}$. Table II summarizes the effect of varying the $\mathrm{Co} / \mathrm{Ni}$ content for alloys containing 3\% $\mathrm{Cr}$ simultaneously with heat treatment on sustained load $\mathrm{da} / \mathrm{dt}$ at $538^{\circ} \mathrm{C}$ and $33 \mathrm{MPa} / \mathrm{m}$. Fe, $\mathrm{Al}, \mathrm{Ti}$ and $\mathrm{Nb}$ were held constant at nominally $26 \%, 5.4 \%, 0.1 \%$ and $3 \%$, respectively.

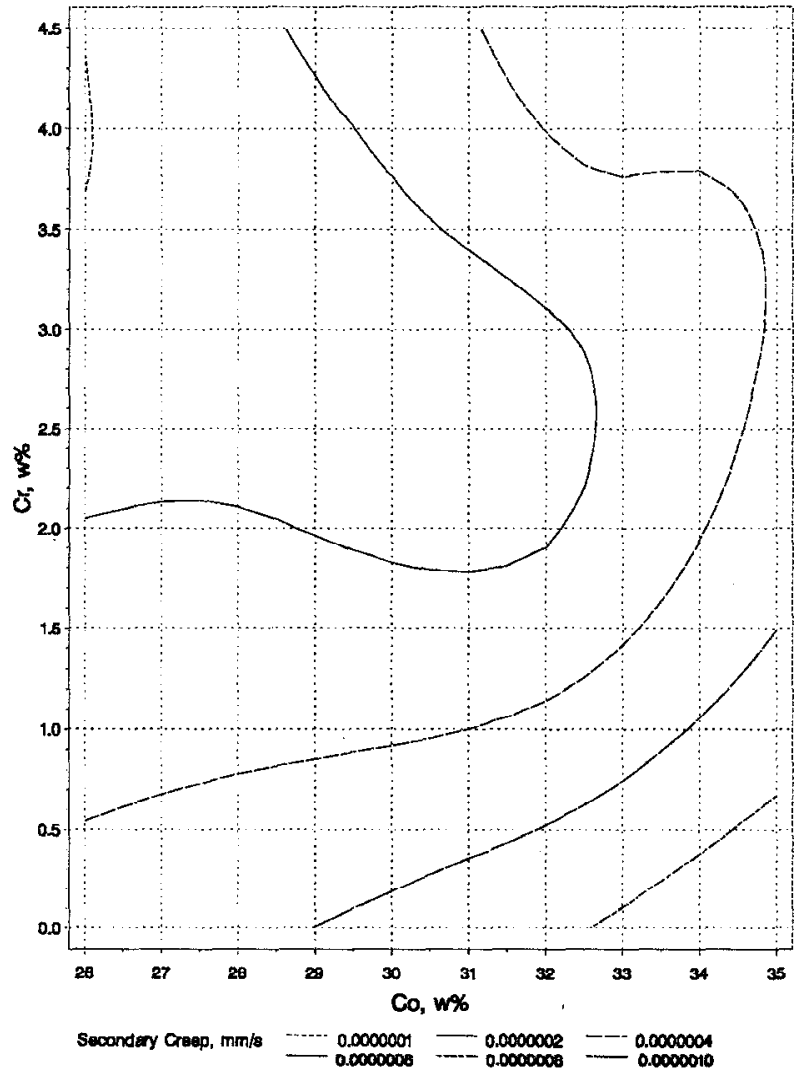

Figure 5 Effect of $\mathrm{Cr}$ and $\mathrm{Co}$ on secondary creep rate at $649^{\circ} \mathrm{C}$ under $380 \mathrm{MPa}$ stress.

Annealing heat treatments were conducted at 982 and $1038^{\circ} \mathrm{C}$ for one hour and air cooled. Aging heat treatments were conducted at 732,788 , and $843^{\circ} \mathrm{C}$ for $16 \mathrm{~h}$ then furnace cooled $55^{\circ} \mathrm{C} / \mathrm{h}$ to $621^{\circ} \mathrm{C}$ for $8 \mathrm{~h}$ and air cooled. Additionally, specimens were given a high temperature solution anneal at $1121^{\circ} \mathrm{C}$ for one hour and air cooled, followed by an intermediate heat treatment at $843^{\circ} \mathrm{C}$ for $2 \mathrm{~h}$, air cooled, and age hardened at $732^{\circ} \mathrm{C}$ for $8 \mathrm{~h}$ furnace cooled to $621^{\circ} \mathrm{C}$ held for $8 \mathrm{~h}$, and air cooled.

Sustained load crack growth was a strong function of the $\mathrm{Co} / \mathrm{Ni}$ content and the heat treatment, as well as interactions between the composition and heat treatment. Regardless of the heat treatment, increasing the Co/ $\mathrm{Ni}$ ratio reduced crack growth rates, though the amount of reduction in $\mathrm{da} / \mathrm{dt}$ depended on both the anneal and aging temperatures. Specimens of $24 \% \mathrm{Ni}$ content consistently failed to sustain crack growth, with cracking repeatedly stalling. When $\mathrm{da} / \mathrm{dt}$ was measurable, rates were less than $0.9 \times 10^{-6} \mathrm{~mm} / \mathrm{s}$. In most cases, the creep crack threshold was above $33 \mathrm{MPa} / \mathrm{m}$. On the other hand, specimens of $33 \% \mathrm{Ni}$ content consistently had the highest $\mathrm{da} / \mathrm{dt}$ for any given combination of annealing and aging temperatures.

Both annealing and aging temperatures had significant effects on $\mathrm{da} / \mathrm{dt}$. Annealing at $982^{\circ} \mathrm{C}$ resulted in lowest crack growth rates for all aging temperatures. Crack growth rates increased significantly in specimens annealed at $1038^{\circ} \mathrm{C}$, by nearly an order of magnitude in specimens containing $30 \%$ or more Ni content. Increasing the aging heat treatment temperature consistently decreased $\mathrm{da} / \mathrm{dt}$ for all annealing temperatures and at all $\mathrm{Ni}$ contents, except for those specimens containing $24 \% \mathrm{Ni}$. 
Table II Effect of Co/ Ni content and heat treatment on da/dt $\left(10^{-6} \mathrm{~mm} / \mathrm{s}\right)$ at $538^{\circ} \mathrm{C}$ and $33 \mathrm{MPa} / \mathrm{m}$.

\begin{tabular}{|c|c|c|c|c|c|c|c|}
\hline Anneal: & \multicolumn{3}{|c|}{$982^{\circ} \mathrm{C}$} & \multicolumn{3}{|c|}{$1038^{\circ} \mathrm{C}$} & $1121^{\circ} \mathrm{C}$ \\
\hline $\begin{array}{c}\text { Aging } \\
\text { Temperatures: }\end{array}$ & $\begin{array}{l}732^{\circ} \mathrm{C}, \mathrm{FC} \\
621^{\circ} \mathrm{C}, \mathrm{AC}\end{array}$ & $\begin{array}{l}788^{\circ} \mathrm{C}, \mathrm{FC} \\
621^{\circ} \mathrm{C}, \mathrm{AC}\end{array}$ & $\begin{array}{l}843^{\circ} \mathrm{C}, \mathrm{FC} \\
621^{\circ} \mathrm{C}, \mathrm{AC}\end{array}$ & $\begin{array}{l}732^{\circ} \mathrm{C}, \mathrm{FC} \\
621^{\circ} \mathrm{C}, \mathrm{AC}\end{array}$ & $\begin{array}{l}788^{\circ} \mathrm{C}, \mathrm{FC} \\
621^{\circ} \mathrm{C}, \mathrm{AC}\end{array}$ & $\begin{array}{l}843^{\circ} \mathrm{C}, \mathrm{FC} \\
621^{\circ} \mathrm{C}, \mathrm{AC}\end{array}$ & $\begin{array}{l}843^{\circ} \mathrm{C}, \mathrm{AC} \\
732^{\circ} \mathrm{C}, \mathrm{FC} \\
621^{\circ} \mathrm{C}, \mathrm{AC}\end{array}$ \\
\hline $\begin{array}{c}24 \% \mathrm{Ni} \\
\text { (HV7498) }\end{array}$ & $\begin{array}{l}\text { crack growth } \\
\text { stalled }\end{array}$ & $<0.2$ & $\begin{array}{l}\text { crack growth } \\
\text { stalled }\end{array}$ & $\begin{array}{l}\text { crack growth } \\
\text { stalled }\end{array}$ & $\begin{array}{l}\text { crack growth } \\
\text { stalled }\end{array}$ & not tested & $\begin{array}{l}\text { crack growth } \\
\text { stalled }\end{array}$ \\
\hline $\begin{array}{c}27 \% \mathrm{Ni} \\
\text { (HV7501) }\end{array}$ & 0.7 & $\begin{array}{l}\text { precrack } \\
\text { fractured }\end{array}$ & $<1$ & 5 & 1.8 & 0.5 & 2 \\
\hline $\begin{array}{c}30 \% \mathrm{Ni} \\
\text { (HV7503) }\end{array}$ & 2 & 1.3 & $<0.1$ & 15 & $\overline{9}$ & 5 & 11 \\
\hline $\begin{array}{c}33 \% \mathrm{Ni} \\
\text { (HV7505) }\end{array}$ & 5.8 & $\begin{array}{l}\text { crack growth } \\
\text { stalled }\end{array}$ & 1.5 & 30 & 35 & 10 & 32 \\
\hline
\end{tabular}

Notes:

1) Annealed at temperature shown for one hour, air cooled.

2) Two-step ages: Initial temperature held for $16 \mathrm{~h}$, furnace cooled $55^{\circ} \mathrm{C} / \mathrm{h}$, to $621^{\circ} \mathrm{C}$ held for $8 \mathrm{~h}$, air cooled.

3) Three-step age: $843^{\circ} \mathrm{C}$ held for $2 \mathrm{~h}$, air cooled. $732^{\circ} \mathrm{C}$ held for $8 \mathrm{~h}$, furnace cooled $55^{\circ} \mathrm{C} / \mathrm{h}$ to $621^{\circ} \mathrm{C}$ held for $8 \mathrm{~h}$, air cooled.

The $\mathrm{da} / \mathrm{dt}$ of the solutionized, intermediate and age hardened specimens also showed strong sensitivity to $\mathrm{Ni}$ content. This study demonstrated that da/dt performance is controlled by the judicious use of combined heat treatment temperatures and times. Exposing specimens to the $843^{\circ} \mathrm{C}$ heat treatment permitted the use of high temperature, solutionizing and grain coarsening anneal.

INCONEL alloy $718 \mathrm{da} / \mathrm{dt}$. There is a considerable amount of $\mathrm{da} / \mathrm{dt}$ data at $649^{\circ} \mathrm{C}$ published for alloy 718 , but little da/dt data at $538^{\circ} \mathrm{C}$. This was data determined by Sadananda and Shahinian from plate using non-optimal composition and thermomechanical processing. ${ }^{5}$ To generate more relevant da/dt data, a fully heat treated turbine engine ring of $38.1 \mathrm{~mm}$ thick by $50.8 \mathrm{~mm}$ high was sacrificed for specimens.

The $\mathrm{da} / \mathrm{dt}$ in the axial and radial orientations were determined at $538^{\circ} \mathrm{C}$ and are shown in Figure 6 . Also plotted on this figure are the $\mathrm{da} / \mathrm{dt}$ results obtained from fully heat treated plate. Compact tension specimens from both the ring and from the plate were heat treated at $954^{\circ} \mathrm{C}$ for $1 \mathrm{~h}$, air cooled, $718^{\circ} \mathrm{C}$ for $8 \mathrm{~h}$ furnace cooled to $621^{\circ} \mathrm{C}$, held for $8 \mathrm{~h}$, and air cooled.

The $\mathrm{da} / \mathrm{dt}$ of the engine ring was dependent on orientation to some degree, with the axial da/dt being lower than the radial da/dt. The ring had significantly better da/dt versus the plate. This was the result of the controlled thermomechanical ring-rolling process and composition intended to result in a controlled microstructure and good crack growth resistance. The $\mathrm{da} / \mathrm{dt}$ of this ring matched the $\mathrm{da} / \mathrm{dt}$ of a $50.8 \mathrm{~mm}$ diameter rod hot rolled and fully heat treated as produced at Inco Alloys International. This range of $\mathrm{da} / \mathrm{dt}$ at $538^{\circ} \mathrm{C}$ was adopted as the goal.

Alloy 783 Engine Ring, Effect of Anneal Temperature. Based on the above examples and several other studies, a composition was selected for evaluating the large scale manufacturing feasibility. The aimpoint composition was $28.5 \% \mathrm{Ni}, 34 \% \mathrm{Co}, 5.4 \% \mathrm{Al}, 3 \% \mathrm{Cr}, 3 \% \mathrm{Nb}$, $0.006 \% \mathrm{~B}$, with $\mathrm{Ti}$ and $\mathrm{Si}$ each less than $0.2 \%$, and $\mathrm{Fe}$ being the balance. The actual composition of heat Y9411Y is given in Table I.

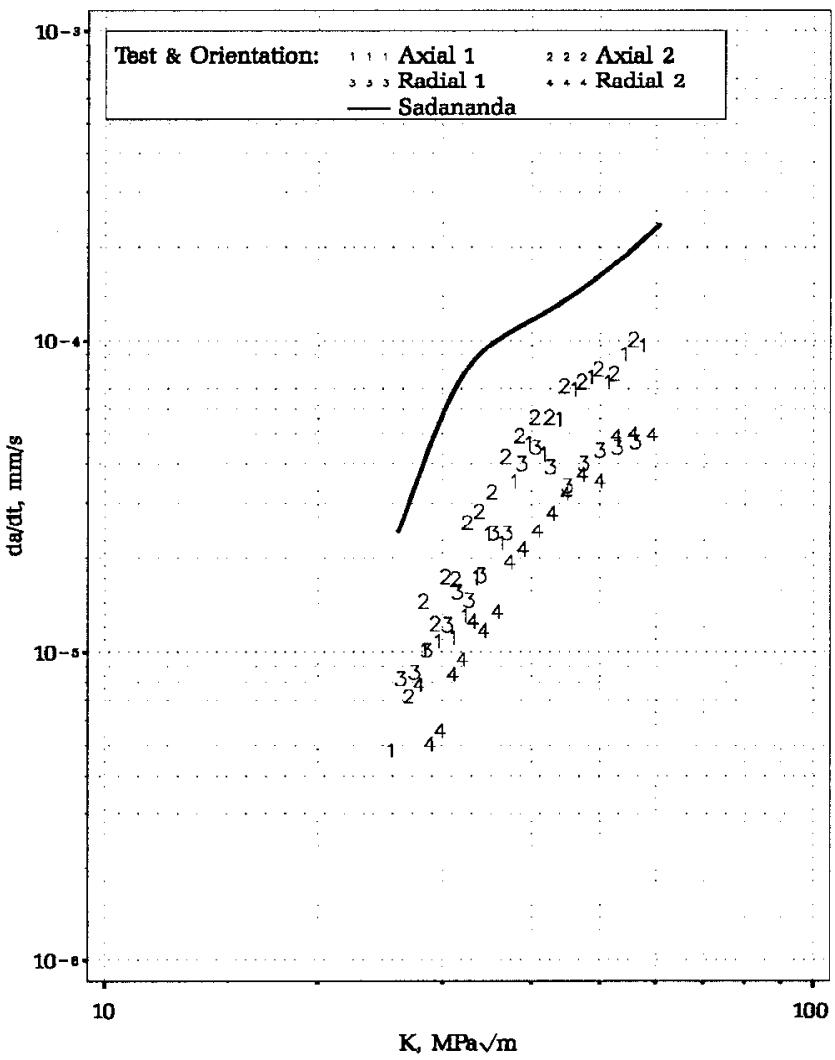

Figure 6 INCONEL alloy $718 \mathrm{da} / \mathrm{dt}$ at $538^{\circ} \mathrm{C}$. Data determined from engine ring and from plate (Sadananda ${ }^{5}$ ). 
Effect of Heat Treatment. Sustained load crack growth performance of INCONEL alloy 783 is also dependent on the heat treatment. This dependency is illustrated by the annealing termperature-aging temperature-da/dt mean response surface shown in Figure 11. This response surface was constructed from the examples shown in this paper combined with dato from other developmental studies, and is valid for compositions nominally containing $28 \% \mathrm{Ni}, 34 \% \mathrm{Co}, 3 \% \mathrm{Cr}$, $5.4 \% \mathrm{Al}, 3 \% \mathrm{Nb}$, and balance $\mathrm{Fe}$. The annealing time at temperature is one hour, and air cooled. The aging heat treatments are based on specimens aged at the temperatures shown for 8 to $16 \mathrm{~h}$, furnace cooled $55^{\circ} \mathrm{C} / \mathrm{h}$ to $621^{\circ} \mathrm{C}$, heid for $8 \mathrm{~h}$, and air cooled. The da/dt shown is at $538^{\circ} \mathrm{C}$ and $33 \mathrm{MPaVm}$ and represents mean values for the heat treatments.

The $\mathrm{da} / \mathrm{dt}$ is maximized when annealed between about 1040 to $1080^{\circ} \mathrm{C}$ regardless of the aging temperature. However, the maximum $\mathrm{da} / \mathrm{dt}$ is highest at aging temperatures around $750^{\circ} \mathrm{C}$ or lower, dropping significantly above $800^{\circ} \mathrm{C}$. The minimum da/dt occurs after annealing below $1020^{\circ} \mathrm{C}$ or above $1100^{\circ} \mathrm{C}$ and aged at temperatures above $800^{\circ} \mathrm{C}$

A wide variety of heat treatment combinations may be used to achieve good da/dt resistance in alloy 783 . Solution annealing at $1120^{\circ} \mathrm{C}$ followed by an intermediate $\beta$ age at $845^{\circ} \mathrm{C}$ for 2 to $4 \mathrm{~h}$, followed by a conventional $\gamma^{\prime}$ precipitation two-step heat treatment of $718^{\circ} \mathrm{C}$ for $8 \mathrm{~h}$ furnace cooling to $621^{\circ} \mathrm{C}$, held for $8 \mathrm{~h}$, and air cooling, has been found to offer a good combination of properties. This heat treatment provides for coarser grain size (ASTM $\# 5$ to $\# 3$ ) for creep resistance, reduces thermomechanically induced anisotropy, and provides for more uniform and controlled fine $\beta$ precipitation throughout the grain boundaries and the microstructural matrix as a whole.

Microstructure. Low da/dt rates in low temperature $\left(<1020^{\circ} \mathrm{C}\right)$ annealed alloy 783 is associated with fine grain and an abundance of globular and intergranular $\beta$ in the microstructure. The microstructure for a specimen from a turbine ring heat treated at $1010^{\circ} \mathrm{C}$ for one

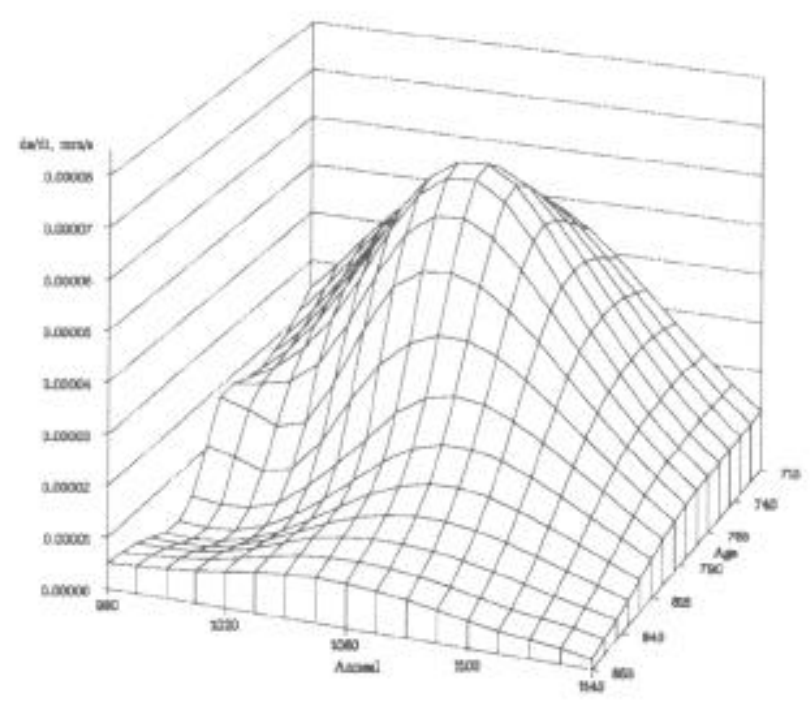

Figure 11 Effect of annealing and aging temperatures on the $\mathrm{da} / \mathrm{dt}$ at $538^{\circ} \mathrm{C}$ and $33 \mathrm{MPa}$ m of INCONEL alloy 783 . hour, air cooled, $760^{\circ} \mathrm{C}$ for $12 \mathrm{~h}$ furnace cooled $55^{\circ} \mathrm{C} / \mathrm{h}$ to $621^{\circ} \mathrm{C}$, held for $8 \mathrm{~h}$, air cooled, is illustrated in Figure 12. The globular $\beta$ precipltates are abundant and uniformly distributed, and effectively pir: grain boundaries. Intergranular $\beta$ precipitation is also present. Overaged $\gamma^{\prime}$ is apparently darkening the grain interiors. Since the aging heat treatment temperatures for this specimen were below $800^{\circ} \mathrm{C}$, the observed $\beta$ is predominantly that which precipitated during the turbine ring thermomechanical processing.

The microstructure of an alloy 783 specimen given a high temperature anneal $\left(1121^{\circ} \mathrm{C}\right.$ for one hour, air cooled) and a $\gamma^{\prime}$ aging heat treatment $\left(718^{\circ} \mathrm{C}\right.$ for $8 \mathrm{~h}$ furnace cooled to $621^{\circ} \mathrm{C}$, held for $8 \mathrm{~h}$, air cooled), is shown in Figure 13. The microstructure of an alloy 783 specimen given the same heat treatment except with an intermediate $\beta$ aging heat treatment, is shown in Figure 14. The microstructure of an alloy 718 compact tension specimen obtained from the engine ring is shown in Figure 15

The armealed and $\gamma^{\prime}$ aged only alloy 783 specimen has essentially "clean" grain boundaries with some undissolved primary $\beta$ particles scattered throughout the microstructure. In contrast, the annealed, $\beta$ and $\gamma$-aged specimen contains extensive intergranular precipitates, as well as uniformly distributed intragranular lenticular $\beta$. The optical microstructure of the alloy 718 specimen is similar in appearance except the intergramular phase in this alloy is primarily $\delta\left(\mathrm{Ni}_{3} \mathrm{Nb}, \mathrm{Ti}\right)$.

Fractographs. The fractographs of the latter three fractured compact tension specimens are also revealing. Creep resistant superalloys fracture intergranularly at $538^{\circ} \mathrm{C}$ when subjected to sustained loading in air. Likewise, fracture in all three specimens, alloy 783 in both heat treated conditions and alloy 718 , followed an intergramular crack path, accompanied with frequent secondary intergranular branch cracks.

The fracture surface of the annealed and $\gamma^{\prime}$-aged alloy 783 specimen, in Figure 16, has very clean grain facets devoid of any significant ductility. Nevertheless, this specimen had da/dt rates superior to alloy 909 (see Table III). The annealed, $\beta$ - and $\gamma$-aged alloy 783 specimen had significantly improved $\mathrm{da} / \mathrm{dt}$, yet the crack path remained the same, see Figure 17. However, the grain facets are rougher in appearance. The grain facet features are probably a combination of

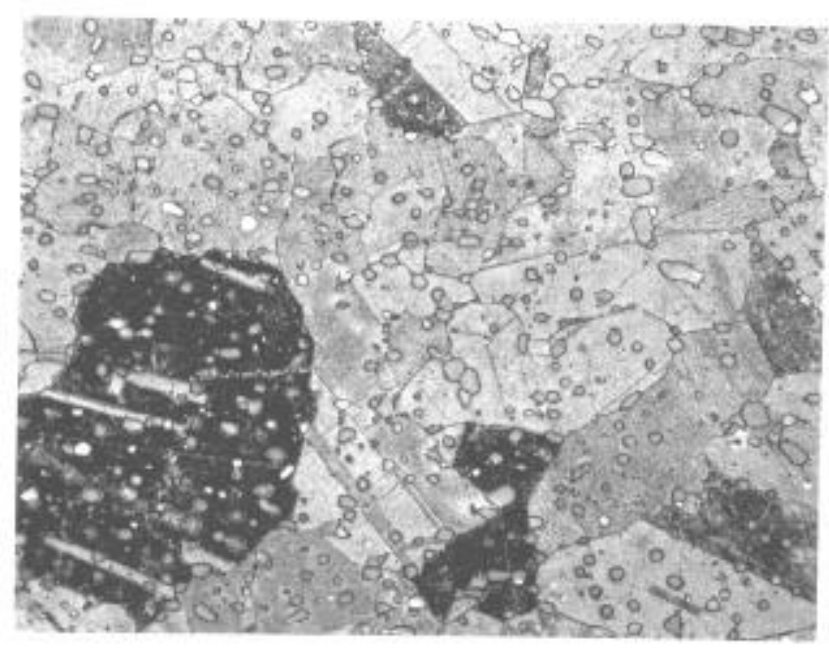

Figure 12 Alloy 783 heat treated $1010^{\circ} \mathrm{C}$ for $1 \mathrm{~h}$, air cooled, $760^{\circ} \mathrm{C}$ for $12 \mathrm{~h}$, cooled $55^{\circ} / \mathrm{h}$ to $621^{\circ} \mathrm{C}$ for $8 \mathrm{~h}$, air cooled. Specimen from turbine ring, circumferential view, $500 \mathrm{x}$. 


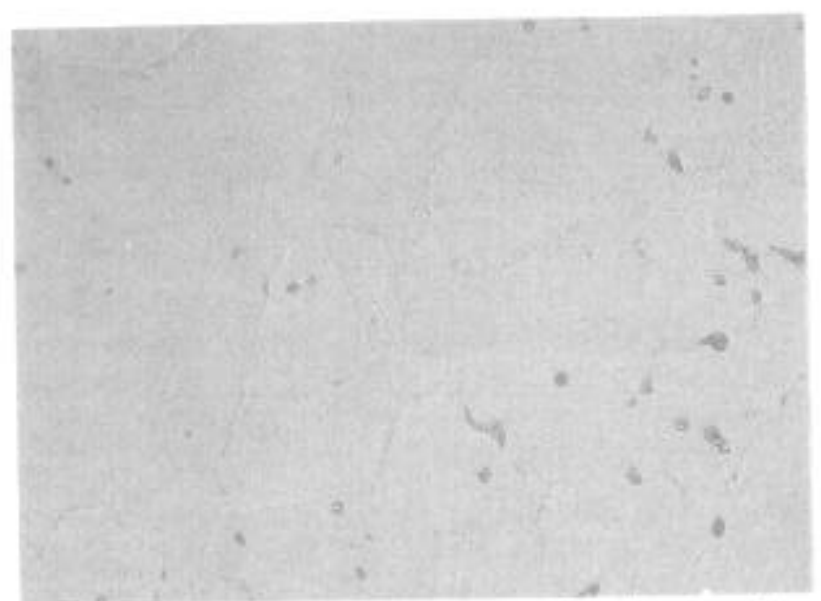

Figure 13 Alloy 783 annealed at $1121^{\circ} \mathrm{C}$ for $1 \mathrm{~h}$, air cooled, aged $718^{\circ} \mathrm{C}$ for $8 \mathrm{~h}$ cooled $55^{\circ} / \mathrm{h}$ to $621^{\circ} \mathrm{C}$ for $8 \mathrm{~h}$, air cooled. Specimen from turbine ring, circumferential view, $500 \mathrm{x}$.

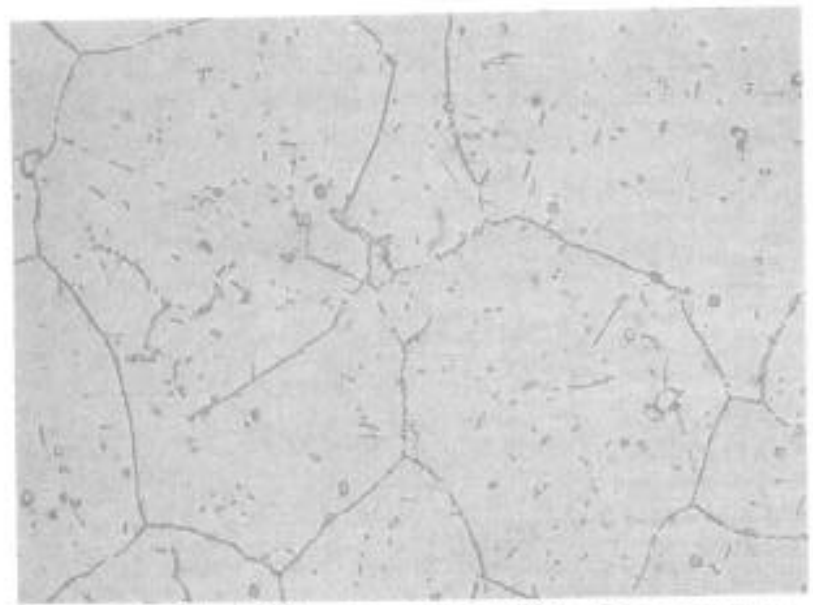

Figure 14 Alloy 783 heat treated $1121^{\circ} \mathrm{C}$ for $1 \mathrm{~h}$, air cooled, $843^{\circ} \mathrm{C}$ for $2 \mathrm{~h}$, air cooled, $718^{\circ} \mathrm{C}$ for $8 \mathrm{~h}$ cooled $55^{\circ} \mathrm{C} / \mathrm{h}$ to $621^{\circ} \mathrm{C}$ for $8 \mathrm{~h}$, air cooled. Specimen from turbine ring, circumferentlal view, $500 x$.

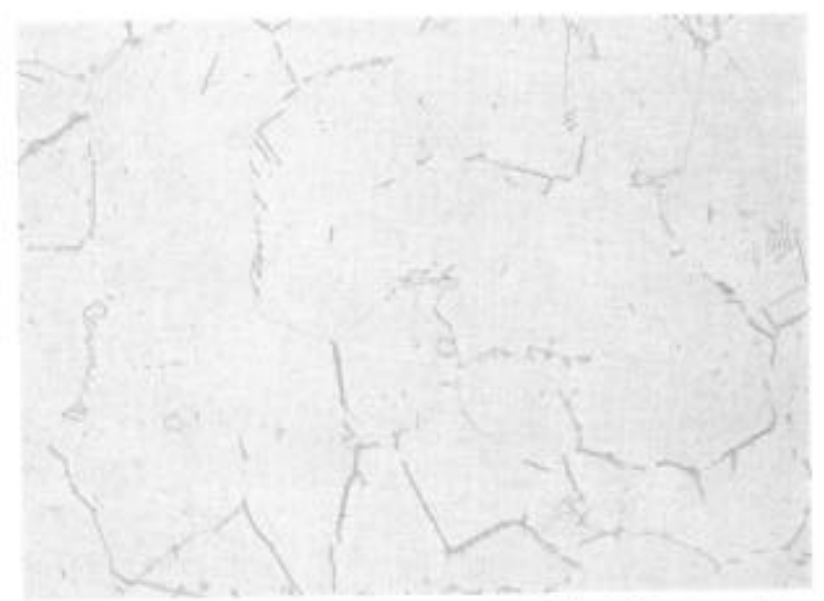

Figure 15 Alloy 718 teat treated at $954^{\circ} \mathrm{C}$ for $1 \mathrm{~h}$, air cooled, $718^{\circ} \mathrm{C}$ for $8 \mathrm{~h}$ cooled $55^{\circ} \mathrm{h}$ to $621^{\circ} \mathrm{C}$ for $8 \mathrm{~h}$, air cooled. Specimen from turbine ring, circumferential view, $500 \mathrm{x}$.

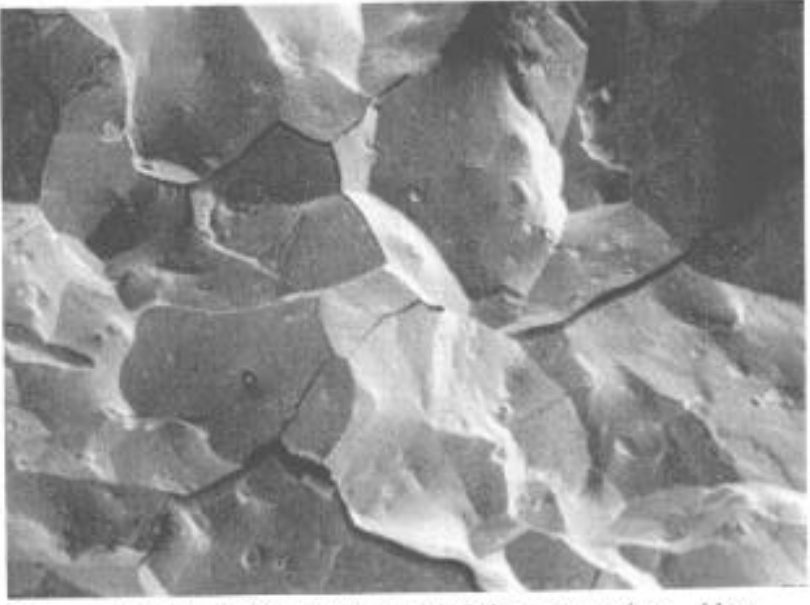

Figure 16 Alloy $783 \mathrm{da} / \mathrm{dt}$ at $538^{\circ} \mathrm{C}$ fracture surface. Heat treated at $1121^{\circ} \mathrm{C}$ for $1 \mathrm{~h}$, air cooled, aged $718^{\circ} \mathrm{C}$ for $8 \mathrm{~h}$, cooled $55^{\circ} \mathrm{h}$ to $621^{\circ} \mathrm{C}$ for $8 \mathrm{~h}$, air cooled. $500 \mathrm{x}$.

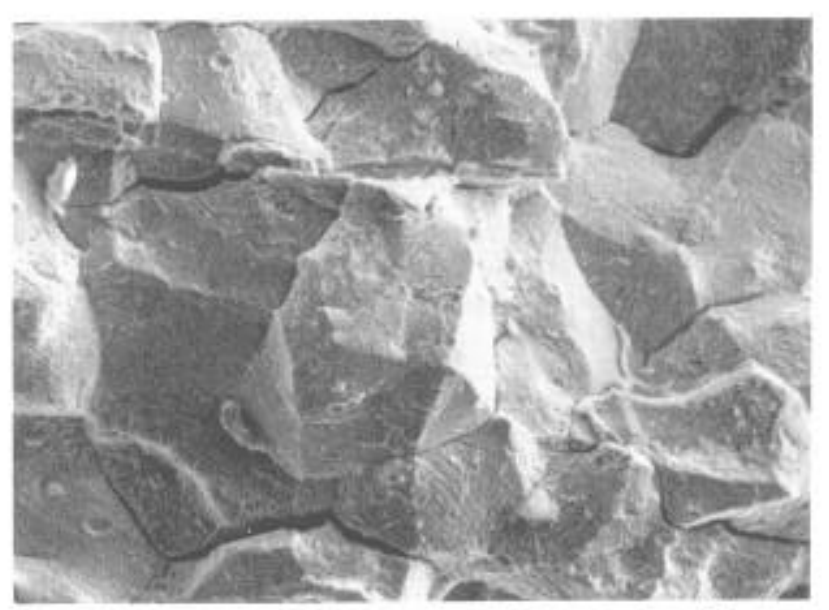

Figure 17 Alloy $783 \mathrm{da} / \mathrm{dt}$ at $538^{\circ} \mathrm{C}$ fracture surface. Heat treated $1121^{\circ} \mathrm{C}$ for $1 \mathrm{~h}$, air cooled, $843^{\circ} \mathrm{C}$ for $2 \mathrm{~h}$, air cooled, $718^{\circ} \mathrm{C}$ for $8 \mathrm{~h}$ cooled $55^{\circ} \mathrm{C} / \mathrm{h}$ to $621^{\circ} \mathrm{C}$ for $8 \mathrm{~h}$, air cooled. $500 \mathrm{x}$.

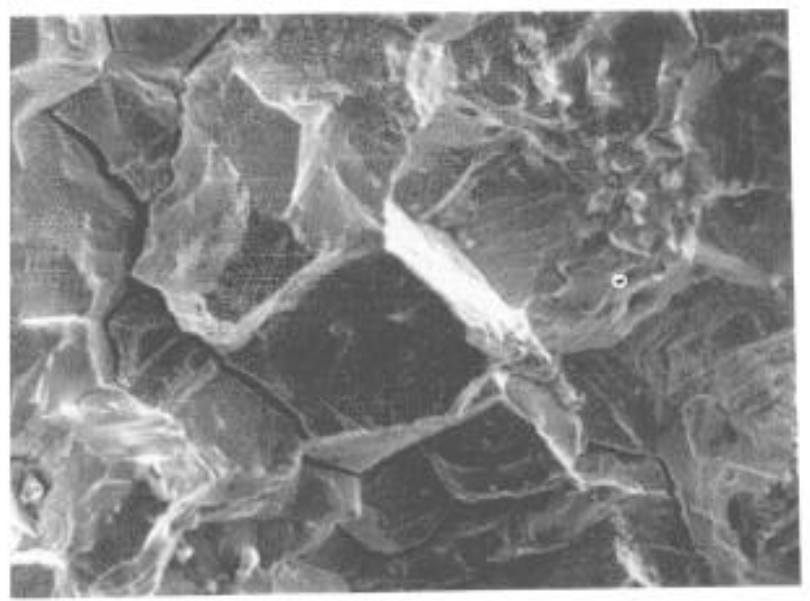

Figure 18 Alloy $718 \mathrm{da} / \mathrm{dt}$ at $538^{\circ} \mathrm{C}$ fracture surface. Heat treated at $954^{\circ} \mathrm{C}$ for $1 \mathrm{~h}$, air cooled, $718^{\circ} \mathrm{C}$ for $8 \mathrm{~h}$ cooled $55^{\circ} / \mathrm{h}$ to $621^{\circ} \mathrm{C}$ for $8 \mathrm{~h}$, air cooled. $500 \mathrm{x}$. 
the oxidation of the grain boundary phases and localized deformation. The alloy 718 specimen fracture surface, shown in Figure 18, is also rougher in comparison with the annealed and $\gamma^{\prime}$-aged alloy 783 fracture surface, with perhaps some slight grain facet deformation observable.

Concluding Comments. It has been demonstrated that sustained load crack growth in air at temperatures between $450^{\circ} \mathrm{C}$ and $700^{\circ} \mathrm{C}$ is strongly driven by oxygen from the environment in most, if not all, superalloys. Although inert environmental da/dt performance was not been shown here, the same is true for INCONEL alloy 783. It is clear from these microstructures and fractographs that alloy $783 \mathrm{da} / \mathrm{dt}$ performance at $538^{\circ} \mathrm{C}$ is largely a result of grain boundary phase formation (or lack of it) and the interaction with the environment. Resistance to sustained load cracking in air is achieved by grain boundary phase engineering in these superalloys.

It is curious to note that the studies leading to the development of alloy 783 provide results congruous with the findings of Andrieu, et al, on alloy $718 .^{8}$ That work showed that Ni-rich oxides were "a prerequisite for a nickel-base alloy to be sensitive to the effect of environment." The studies on $\gamma-\gamma^{\prime}-\beta$ alloys showed that the reduction of bulk $\mathrm{Ni}$ content resulted in significant improvements in $\mathrm{da} / \mathrm{dt}$ resistance, and thus grain boundary environmental resistance. While this certainly has to do with the stabilization of grain boundary $\beta$ phases, alteration of $\gamma$ ' morphology, and reduction in creep resistance, it also may imply effects on environmental-grain boundary micro-oxidation interactions.

Secondly, it was also concluded that "high intergranular stresses resulting from strain incompatibilities due to either slip character or microstructural inhomogeneities, or both" were also a requirement for a strong environmental effect. The presence of intergranular precipitates as different in composition and structure as $\beta$ (ordered $\mathrm{BCC}$ ) in alloy 783 and $\delta$ (orthorhombic) in alloy 718 provide increased environmental $\mathrm{da} / \mathrm{dt}$ resistance over that of precipitate-free grain boundaries in these alloys. It has been demonstrated in INCONEL alloy X-750 that even grain boundary $\mathrm{M}_{23} \mathrm{C}_{6}$ phases can aid in the reduction of environmental sensitivity to oxygen as measured by sustained load crack growth. ${ }^{9}$. With intergranular precipitates so diverse in composition and morphologies, one is led to conjecture that some of the beneficial effect on da/dt at $538^{\circ} \mathrm{C}$ is due to altered (ie, reduced) intergranular strain incompatibilities. These observations offer future guidance (eg, the need for increased attention to practical grain boundary micro-engineering in elevated temperature superalloy development) and hope for new superalloys having improved environmental crack growth resistance.

\section{Summary}

INCONEL alloy 783 is a controlled low thermal expansion, oxidation resistant $\gamma-\gamma^{\prime}-\beta$ superalloy having sustained load crack growth resistance in air environments. Crack growth resistance was achieved by composition (optimized $\mathrm{Co} / \mathrm{Ni}$ and $\mathrm{Cr}$ content) and heat treatment control, and is essentially equivalent to that of INCONEL alloy 718 in stress intensity ranges of 20 to $60 \mathrm{MPa} V_{\mathrm{m}}$. Crack growth resistance is attained by the controlled precipitation of fine $\beta$ particulates in grain boundaries, either by thermomechanical processing with fine grain annealing $\left(980^{\circ} \mathrm{C}\right)$, or preferrably by solution annealing $\left(1120^{\circ} \mathrm{C}\right)$ and using intermediate $\beta$ re-precipitation heat treatments $\left(845^{\circ} \mathrm{C}\right.$ for 2 to $4 \mathrm{~h}$, air cool). Primary strengthening is achieved by $\gamma^{\prime}$ aging heat treatment at $718^{\circ} \mathrm{C}$ for $8 \mathrm{~h}$ furnace cooled to $621^{\circ} \mathrm{C}$, held for $8 \mathrm{~h}$, and air cooled.

\section{Acknowledgments}

SEM fractographs were prepared by Frank J. Veltry. The authors also thank Bob Neugebauer and staff of Martest, Inc., for their efforts with crack growth testing. Also contributing to the development work were D. F. Smith, L. I. Stein, M. A. Moore, and M. A. Holderby.

\section{$\underline{\text { References }}$}

1. D.F.Smith and J.S.Smith, "A History of Controlled, Low Thermal Expansion Superalloys," Physical Metallurgy of Controlled Expansion Invar-Type Alloys, ed. K.C.Russell and D.F.Smith, The Metallurgical Society, Warrendale, PA, 1990, pp 253-272.

2. E.A.Wanner, D.A.Antonio, D.F.Smith, J.S.Smith, "The Current Status of Controlled Thermal Expansion Superalloys," Journal of Metals, 43, 3, 1991, pp 38-43.

3. K.A.Heck, D.F.Smith, M.A.Holderby, J.S.Smith, "Three-Phase Controlled Expansion Superalloys with Oxidation Resistance," Superalloys 1992, ed. S.D.Antolovich, et.al., The Metallurgical Society, Warrendale, PA, 1992, pp 217-226.

4. K.A.Heck, J.S.Smith, R.Smith, "INCONEL alloy 783: An Oxidation Resistant Low Expansion Superalloy for Gas Turbine Applications," Turbo Expo '96, June, 1996, Birmingham, UK, to be published.

5. K. Sadananda and P. Shahinian, "Creep Crack Growth in Alloy 718," Mot. Trans. A, Vol. 8A, pp. 139-449, March, 1977.

6. James Clawson Jr. and Jed Lyons, "The Effects of Heat Treatment on the Microstructure of INCONEL alloy 783," Scripta Materialia, in publication, 1996.

7. J. S. Smith, J. H. Weber, and H. W. Sizek, "Control of StressAccelerated Oxygen-Assisted Cracking of INCOLOY alloy 908 Sheath For $\mathrm{Nb}_{3} \mathrm{Sn}$ Cable-In-Conduit," Advances in Cryogenic Engineering, in publication, 1996.

8. E. Andrieu, G. Hochstetter, R. Molins, and A. Pineau, "Oxidation and Intergranular Cracking Behaviour of Two High Strength Ni-Base Superalloys," Corrosion-Deformation Interactions, Fontainbleu, France, 5-7 Oct. 1992, Les Editiòns de Physique, ed. T. Magnin and J. M. Gras, Avenue du Hoggar, Zone Industrielle de Courtaboeuf, B. P. 112, F-91944 Les Ulis Cedex A, France, pp. 477-491, 1993.

9. S. Floreen, "Effects of Environment on Intermediate Temperature Crack Growth in Superalloys," Micro and Macro Mechanics of Crack Growth, The Metallurgical Society of AIME, pp. 177-184, 1982. 